\section{Old secrets on the market}

\section{San Francisco}

As Cold War tensions evaporate and the Soviet Union flounders economically, the Soviet Union has begun selling its technology, even sensitive technology with military potential, in the West. Last week, a California entrepreneur completed negotiations for the sale to the US government, at a price of $\$ 10$ million, of an advanced Soviet nuclear reactor for use in space. Just two years ago, even the reactor's existence was a closely guarded secret.

The device is a Topaz II reactor designed to power satellites and space stations. Its design is different from and more advanced than those under development in the United States, according to Joseph Wetch of San Jose, California, who orchestrated the agreement. The high-power system may have a variety of applications, including powering communications satellites, radar systems and even the first manned lunar outpost. The reactor is 12 feet high, six feet in diameter and weighs one ton. Its lifetime is estimated at five years.

For the United States, the advantages of the Topaz II reactor is that it uses thermionic rather than thermoelectric conversion to obtain electricity from the reactor heat. As designed, the system can generate up to 6 kilowatts of power, and is probably more economical than solar cells when such a large output is required.

Wetch, who has spent two years negotiating the reactor agreement, believes there remains plenty of untapped science and technology in the Soviet Union. Obtaining it, however, is another matter, requiring good relationships with Soviet scientists and considerable patience with government bureaucracies. Chief among the obstacles were the high US import duty and long delays in the US Commerce Department.

Wetch has a special interest in nuclear space reactors, having been the principal developer of the first, known as the SNAP-10a, in 1965. Shortly after the reactor's first use in space flight, the budget of the US research programme was squeezed, and has been almost dormant for 15 years. The Soviet design now acquired may be able to provide power for space systems at lower costs than solar cells or liquid-fuel systems now in use. The Topaz II will be demonstrated and tested initially in Albuquerque, New Mexico, by a consortium of researchers from academic, industrial and national laboratories, using a Soviet electrical heater rather than the nuclear fuel used in orbit.

Meanwhile, Wetch is working on several other agreements through a joint venture known as INERTEK created

\title{
1990 warmest year on record
}

\section{London}

THE Earth's surface was, on the average, warmer in 1990 than in any year since records began in the mid-nineteenth century. The 1990 value for global mean surface temperature, released last week by the

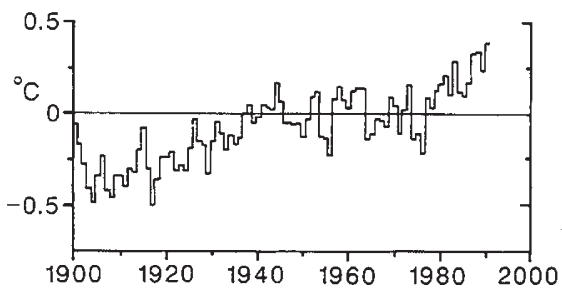

Global mean surface temperature since 1990 relative to the mean from 1951-80.

UK Meteorological Office and the University of East Anglia (UEA)'s Climatic Research Unit, exceeded the previous record, in 1988 , by $0.05^{\circ} \mathrm{C}$. But it is still too early to say with certainty whether the recent warmth is due to the build-up of greenhouse gases in the atmosphere.

Six of the seven warmest years on record have occurred since 1980 , making the past decade the warmest ever recorded. The UEA team is examining the link between the observed warming and the concentralion of greenhouse gases in the atmosphere. The global mean surface temperature is too simple a measure to be of any use, so the UEA researchers are working with temperature values for each of the squares of a worldwide grid, comparing the data over the past century with predictions from computer models of warming under the greenhouse effect. "We think we're beginning to see a link", says Phil Jones, from UEA.

Jones says that the stratosphere appears to be cooling, as predicted by the greenhouse theory. But there are some minor discrepancies: the stratospheric cooling is slower than expected, and surface warming is greater at mid-latitudes and less at the poles than in computer simulations of greenhouse warming.

The Meteorological Office/UEA value is the most reliable calculation of the global mean surface temperature, based on data from land- and sea-based monitoring stations. A similar value produced by the NASA Goddard Institute for Space Studies is calculated from land-based data alone.

Peter Aldhous between his company, International Scientific Products, and Soviet research organizations. He believes that electronics technology for space and ceramic and metallurgical technologies will be among the fertile areas for future Soviet technology transfers. Elizabeth Schaefer

\section{OPEN LETTER}

\section{A message from Vilnius}

\section{January 1991}

ON Monday this week, Nature received the following plea from scientists in Estonia, addressed to the worldwide scientific community:

"At this moment, when Soviet armed forces, starting in Lithuania, and with no respect for human life, are attempting to eliminate democratic structures, freely and rightfully elected parliaments and their appointed executives, we wish to state the following:

The West must acknowledge that the traditional liberal Western view on the future of the Soviet Union and its influence on world peace and stability is now out of date. A more realistic assessment is needed, based on the long history and traditions of the Soviet brand of imperialism. These can be traced back to the Civil War, the occupation and annexation of independent states in 1939 - 1940, to Hungary in 1956, Czechoslovakia 1968, Afghanistan and to more recent events in Tbilisi, Baku and elsewhere.

Those who support this imperialist ideology in the USSR, sacrificing half the national income to the military industrial complex, are today set on getting compensation for the loss of the 'Socialist camp'.

The only way in which the Western democracies can withstand the rising antiperestroika tide and its neo-imperialistic attitudes is by open and clear support, not only of individuals but also of the democratically elected legislative bodies of the republics. Western governments should look behind the rhetoric and decide which carries the most promise for peace in Europe and elsewhere: a unitarian empire with constant lapses into brutality, or a democratic community of free states, the Russian federation among them.

We ask all scientists to persuade their governments to take a strong and unequivocal position in supporting Lithuania, the other Baltic states and freedomseeking republics of the entity still referred to as the Soviet Union."

The message is signed by Professor Richard Wellems, director of the Estonian Biocentre, who is also a member of the praesidium of the Estonian Academy of Sciences. He says that he writes on behalf of scientists of the Estonian Academy of Sciences and universities, the Estonian Union of Scientists, Estonian Science Council and the Estonian Science Fund Council. 